\title{
Physiological-enzymatic characteristics and inoculation of mycelial strains of Descolea antarctica Sing. in Nothofagus seedlings
}

\author{
Eduardo Valenzuela* \\ Instituto de Microbiología \\ Facultad de Ciencias \\ Universidad Austral de Chile \\ Campus Isla Teja, Casilla 167 \\ Valdivia, Chile \\ Tel: 5663221296 \\ Fax: 5663215295 \\ E-mail: evalenzu@uach.cl

\section{Joseline Hipp} \\ Instituto de Microbiología \\ Facultad de Ciencias \\ Universidad Austral de Chile \\ Campus Isla Teja, Casilla 167 \\ Valdivia, Chile \\ E-mail: joselinehipp@uach.cl
}

Claudia Alonso

Instituto de Microbiología Facultad de Ciencias Universidad Austral de Chile

Campus Isla Teja, Casilla 167 Valdivia, Chile

Tel: 5663221296

E-mail: calonso@uach.cl

\section{Roberto Godoy}

Instituto de Botánica

Facultad de Ciencias

Universidad Austral de Chile

Campus Isla Teja, Casilla 567

Valdivia, Chile

Tel: 5663221365

Fax: 5663221313

E-mail: rgodoy@uach.cl

Miren Alberdi ${ }^{\#}$

Instituto de Botánica

Facultad de Ciencias

Universidad Austral de Chile

Campus Isla Teja, Casilla 567

Valdivia, Chile

Tel: 5663221448

Fax: 5663221313

E-mail: malberdi@uach.cl

Maricel Alvarez

Instituto de Botánica

Facultad de Ciencias

Universidad Austral de Chile

Campus Isla Teja, Casilla 567

Valdivia, Chile

Tel/Fax: 5663221313

E-mail: malvarez@uni-bremen.de

Isabel Saavedra

Instituto de Botánica

Facultad de Ciencias

Universidad Austral de Chile

Campus Isla Teja, Casilla 567 Valdivia, Chile 
Tel/Fax: 5663221313

E-mail: isabelsaavedra@uach.cl

Financial support: Proyecto FONDECYT 1040913.

Keywords: cellulose, ectomycorrhizal fungi, Nothofagus, $\mathrm{pH}$, phosphatase, temperature.

Present address: "Instituto de Química, Facultad de Ciencias, Universidad de la Frontera, Temuco, Casilla 54-D.

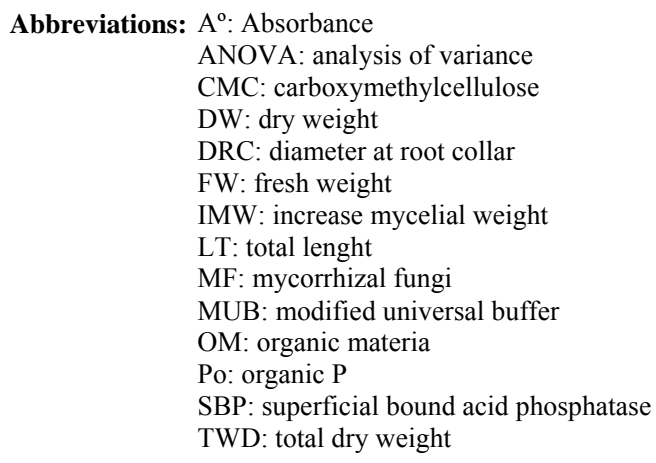

At present, reforestation has focused on native forests with anthropogenic intervention and eroded soils. There is interest in producing Nothofagus seedlings which can overcome adverse conditions encountered on reforestation sites. It is necessary to find new fungi that can be utilized as mycorrhizal inoculants and that enable the seedlings to increase their tolerance to adverse conditions. Two ectomycorrhizal strains of the fungus Descolea antarctica (D1 and D2) were cultured at different temperatures, $\mathrm{pH}$ levels and the activities of amylases, cellulases, and phosphatases were determined. In greenhouse and nursery trials, the growth responses of inoculated Nothofagus obliqua seedlings were evaluated. D1 and D2 exhibited the highest growth rates at $23^{\circ} \mathrm{C}$. Both strains grew at $\mathrm{pH}$ levels from 4 to 11 . The highest enzymatic activities were registered for amylase (57.2 $\mathrm{mg}$ glucose $/ \mathrm{ml} * \mathrm{~g}$ of mycelium * hr) and acid phosphatases $(58.1 \mathrm{mg} p$-nitrophenol $/ \mathrm{ml}$ * $\mathrm{g}$ of mycelium * hr) at $37^{\circ} \mathrm{C}$, and acid phospatases $(1.720 \mathrm{mg} p$ nitrophenol $/ \mathrm{ml} * \mathrm{~g}$ of mycelium $* \mathrm{hr}$ ) and alkaline phosphatases $(1.360 \mathrm{mg} p$-nitrophenol $/ \mathrm{ml} * \mathrm{~g}$ of mycelium * hr) at $\mathrm{pH} 4$ and $\mathrm{pH} 11$, respectively. We conclude that suitable $N$. obliqua seedlings for use in reforestation were obtained using $D 2$ as inoculant.

Chile's native forests have many values, according to diverse points of view, which in their totality make these forests a focus of scientific and commercial interest (Echeverria et al. 2006; Godoy et al. 2006; Heads, 2006). Sixty percent of these forests' land area is concentrated in south-central Chile, and at present the degradation of the forests by anthropogenic disturbances is evident; for this reason there is a strong interest in the development of techniques for improving the production and the establishment of native tree species with the goal of reforestation (Echeverria et al. 2006; Peri et al. 2006). The representatives of the genus Nothofagus are especially strongly emphasized for reforestation. Nothofagus distribution is restricted to the Southern Hemisphere, and 10 of its approximately 40 species are native to Chile (Heads, 2006; Salas et al. 2006). The successful establishment of Nothofagus plantations is strongly influenced by the capacity of the Nothofagus seedlings to withstand adverse conditions (drought, flooding, extreme temperatures, etc.); moreover, they must have an appropriate root system to promote effective absorption of water and nutrients. It therefore makes it necessary to conduct studies that permit the identification of the Nothofagus plants' innate and external mechanisms for overcoming adverse conditions (stresses). On the other hand, Garrido (1988) and Godoy et al. (2006) indicate that mutualistic symbiotic associations (ectomycorrhizae) are established between the roots of Nothofagus species and the hyphae of various species of mycorrhizal fungi (MF). In mycorrhizal associations, the hyphae of the MF facilitate the associated plants' absorption of nutrients. Moreover, Alvarez et al. (2004) indicate that the hyphae of the MF, due to their innate enzymatic and physiological processes, also assist the plants in overcoming adverse conditions. Because of this, authors like Clemmensen and Michelsen (2006), Cardoso and Kuyper (2006) and Correa et al. (2006), have indicated that an ability to overcome different types of stress (hydric, $\mathrm{pH}$, temperature, etc.) is among those desirable aspects that a mycorrhizal fungus must possess.

As was pointed out in the preceding paragraph, it is possible to find a great variety of mycorrhizal fungi in Nothofagus forests that vary qualitatively and quantitatively according to the forest's geographic location, the stage of

*Corresponding author 
development of the forest's trees, the catastrophic natural events that have occurred (excessive rainfall, droughts, fires, etc.), and the anthropogenic intervention to which the forest has been subjected (Garrido, 1988; Valenzuela et al. 1999; Godoy et al. 2006). Among those mycorrhizal fungi that have broad geographic distributions (Chile and Argentina), Descolea antarctica Sing. can be found in pristine Nothofagus forests, both managed and unmanaged, in sites where the Nothofagus forest has been harvested and reforested with Nothofagus spp., and in parks where different species of Nothofagus, that were obtained from native forests, are cultivated. According to Singer (1986), $D$. antarctica forms ectomycorrhizae with various species of Nothofagus. Moreover, its basidiocarps may be found in decomposing wood deposited on the soil; $D$. antarctica can therefore be said to behave as a facultative ectomycorrhizal fungus. This gives it a great advantage over other species that are obligate ectomycorrhizal fungi, since, in the absence of its arboreal hosts, $D$. antarctica can survive as a saprophyte in the soil. Because it is a facultative ectomycorrhizal fungus that associates with various species of Nothofagus, D. antarctica appears to be a good option for use as an artificial inoculant of Nothofagus spp. or to potentiate the production of forest plantations. However, it is necessary to understand the physiological, biochemical, nutritional, and other aspects of this fungus, as well as its ability to tolerate and overcome various kinds of adverse conditions. One must take these aspects into account when selecting a mycorrhizal fungus to use as an inoculant.

Because there are few studies of $D$. antarctica in this context, our working group first decided to determine, in the laboratory, the growth of two strains of $D$. antarctica at different temperatures and $\mathrm{pH}$ levels. Our group also decided to evaluate the amylase, cellulase, and phosphatase enzymes, because the carbon (C) content is lower in soils that have been intensively utilized for agriculture and forestry. In agricultural soils, burning of post-harvest residues and plowing, among other activities, have brought about alterations in the distribution and stability of soil aggregates, which have been reflected by processes of erosion and oxidation of organic material $(\mathrm{OM})$, with a consequent decrease in the soil's productive capacity. In forest soils, the harvest of trees is effectively a removal of $\mathrm{C}$ from the site. Moreover, the post-harvest forest soil is bare and exposed to erosion (aeolian, hydric, etc.) and oxidation of its OM. In consequence, at the time that a degraded soil is reforested with mycorrhized plants, it is important to have already determined the enzymatic potential of the fungus that could eventually be used as a mycorrhizal inoculant. It is also important to evaluate the fungal enzymes that are found to be involved in the $\mathrm{C}$ cycle (i.e., amylases, cellulases, proteases, etc.) because the fungal mycelium, external to the mycorrhized plant's root, must provide a large amount of the $\mathrm{C}$ that the fungus needs in order to be able to continue growing. This growth depends upon the hydrolyzation of C-based compounds present in the soil, mediated by the secretion of enzymes, and later upon the absorption of the subunits (simple sugars) generated by the enzymatic action. Moreover, these subunits permit the growth of other microorganisms, which, as a result of their metabolic activities, can excrete a series of substances that can stimulate the plant's growth or inhibit possible phytopathogens. $\mathrm{C}$ is mineralized and recirculated in this manner. Furthermore, according to texts on fungal biology, such as Deacon (1988) and Miles and Chang (1997), among others, amylase and cellulase allow one to determine whether a fungus behaves as a primary or secondary saprophyte (cellulolytic) in the degradation of plant remains. The phosphatases indicate a fungus' capacity to hydrolyze the phosphorylated organic molecules that are found in the environment, and thereby obtain organic $\mathrm{P}$ (Po), which, in the case of mycorrhizal fungi, is the principal nutrient that they translocate to the plants. A very
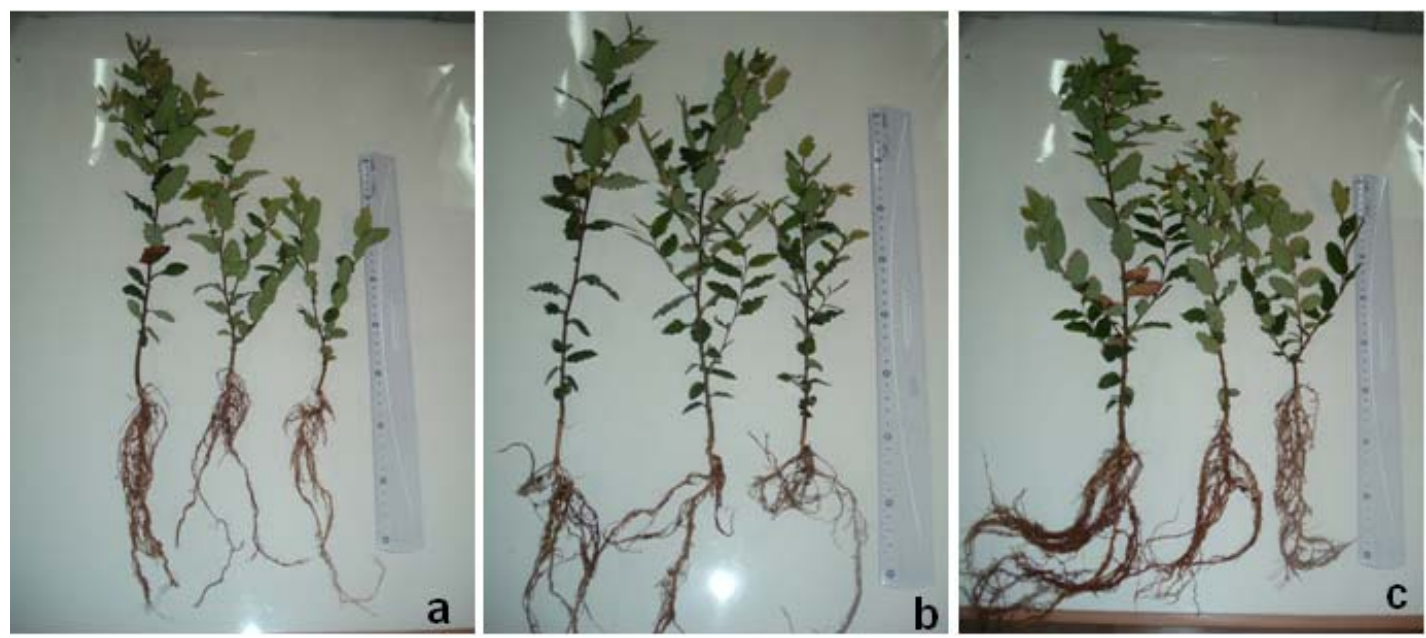

Figure 1. Nothofagus obliqua plants grown in the greenhouse.

a) control plants.

b) plants treated with strain D1 of Descolea antarctica.

c) plants treated with strain D2 of D. antarctica. 
small fraction of the Po in soil consists ofsimple molecules, such as nucleotides, phospholipids andsugar phosphates. The low concentrations of these molecules are due to their high degradability. More complex Po in soil organic material becomes increasingly available for mineralization as $\mathrm{C}$ is mineralizedand $\mathrm{C} / \mathrm{P}$ ratios decrease. The factors that determine $\mathrm{C}$ mineralization, such as the quality of the organic material $(\mathrm{C} / \mathrm{N}$ and $\mathrm{C} / \mathrm{P}$ ratios, lignin content, etc.) and the physical factors that influence microbial activity (e.g., temperature, water, $\mathrm{O}_{2}$, and $\mathrm{pH}$ ) therefore also affect Po mineralization. Biochemical mineralization of Po, i.e., the specific cleavage of P-ester bonds, depends on the stability of the ester bonds and their accessibility for enzymatic attack, on the concentrations of compatible enzymes and substratesin the soil, and on the biotic and abiotic factors that inhibitenzymatic activity (Joner et al. 2000). The determination of phosphatases in D. antarctica is also important because most of the Po in southern Chile's volcanic soils is found in an organic form that is not highly available. Taking into account that cultivated $D$. antarctica can be utilized as a mycorrhizal inoculant for Nothofagus plants, it was decided to determine the variation, at different temperatures and $\mathrm{pH}$ levels, the activities of the aforementioned enzymes of $D$. antarctica, as has been recommended by Joner and Johansen (2000), Sanchez et al. (2001) and Shi et al. (2002). This was done because most of the time the Nothofagus plants are first grown in nurseries and are later brought to sites that will be reforested or where new plantations will be established. During their growth in the nursery as well as in the field, these plants are subjected to different $\mathrm{pH}$ levels, temperatures, nutritional conditions, etc. Finally, it was also decided to determine, both in the greenhouse and in the nursery, the adaptive responses of Nothofagus obliqua seedlings inoculated with two strains of the ectomycorrhizal fungus, $D$. antarctica. The objective was to determine which of the two strains of $D$. antarctica is more effective, and which could increase $N$. obliqua's capacity to become established in forest plantations in south-central Chile. This was evaluated using morphological variables, morphological indices, and quality indices determined for Nothofagus plants that have and have not been treated with both strains of $D$. antarctica.

\section{MATERIALS AND METHODS}

General background of the D1 and D2 Descolea antarctica strains' origins and characteristics: strain D1 was obtained from a basidiocarp of $D$. antarctica collected in soil under Nothofagus sp. at Rebellín, Valdivia, Chile. Strain D2 was obtained from a basidiocarp of $D$. antarctica collected in soil under Nothofagus sp. at Popoen, Osorno, Chile. The mycelial strains D1 and D2 were obtained in pure culture from basidiocarps using the protocol described in Molina and Palmer (1982). The basidiocarps were longitudinally cut, and $0.3 \mathrm{~cm}^{2}$ pieces of pseudotissue were aseptically removed from between the pileus and stipe of each basidiocarp. These pieces were cultivated in Petri dishes containing malt extract agar 2\% Merck (MEA 2\%) and incubated at $23^{\circ} \mathrm{C}$ for 7 days. The obtained cultures were sub-cultivated, in accordance with their microscopic characteristics (septate hyphae with or without clamps and capitate cystidia), in tubes with MEA $2 \%$, to finally obtain strains D1 and D2 of D. antarctica (the strains are preserved at the Universidad Austral de Chile). There are no macroscopic or microscopic differences between strains D1 and D2: colonies $72 \mathrm{~mm}$ in diameter, creamy to whitish,

Table 1. Mean values of the increase of mycelial weights for strains D1 and D2 of Descolea antarctica cultured in malt broth at different temperatures.

\begin{tabular}{|c|c|c|c|}
\hline Strains & Temperature $\left({ }^{\circ} \mathrm{C}\right)$ & DW $(\mathbf{g})$ & IMW (g) \\
\hline & 4 & $0.04 \pm 0.0033 \mathrm{e}$ & $0.01 \pm 0.0033 \mathrm{e}$ \\
\hline D1 & 23 & $0.37 \pm 0.0230 \mathrm{~b}$ & $0.34 \pm 0.0230 \mathrm{~b}$ \\
\hline & 37 & $0.04 \pm 0.0058 \mathrm{e}$ & $0.01 \pm 0.0033 \mathrm{e}$ \\
\hline & Control = 150 $\mathrm{C}$ & $0.08 \pm 0.0058 \mathrm{de}$ & $0.05 \pm 0.0033 \mathrm{de}$ \\
\hline & 4 & $0.13 \pm 0.0153 \mathrm{~d}$ & $0.10 \pm 0.0153 \mathrm{~d}$ \\
\hline D2 & 23 & $0.51 \pm 0.0033 \mathrm{a}$ & $0.49 \pm 0.0033 \mathrm{a}$ \\
\hline & 37 & $0.20 \pm 0.0067 \mathrm{c}$ & $0.17 \pm 0.0100 \mathrm{c}$ \\
\hline & Control $=15^{\circ} \mathrm{C}$ & $0.11 \pm 0.0058 \mathrm{~d}$ & $0.08 \pm 0.0067 \mathrm{~d}$ \\
\hline
\end{tabular}

DW: mycelial dry weight; IMW: increase of mycelial weight. Values with different letters in a column differ significantly from one another $(p \leq 0.05) . n=24$. 
texture subfelty. Advancing zone appressed. Reverse whitish. Hyphae hyaline of $2.8-5.6 \mu \mathrm{m}$ diameter, septate with or without clamps. Hyphae in center of colony anastomosed. Cystidia capitate, not very abundant, of 4 $7.6 \mathrm{~cm}$ in length, hyaline. The colonies' maximum growth $(90 \mathrm{~mm})$ was determined to occur after 15 days of culture at $23^{\circ} \mathrm{C}$ on MEA $2 \%$ for both mycelial strains (D1 and D2).

\section{Determination of growth of the mycelial strains D1 and D2 of Descolea antarctica at different temperatures}

Flasks, each containing $200 \mathrm{ml}$ of MB 2\%, prepared as indicated by the supplier Merck ( $2 \%$ malt broth: dissolve 2 $\mathrm{g}$ malt extract in $200 \mathrm{ml}$ distilled water and autoclave at $121^{\circ} \mathrm{C}$ for $15 \mathrm{~min}$ ), were individually inoculated with a circle of agar with mycelium obtained from a young culture (15 days) of the appropriate strain's mycelium. All of the agar circles with mycelium measured $1.5 \mathrm{~cm}$ in diameter, and each one of them was aseptically weighed on a Sartorius 2462 analytical balance. Afterwards, three inoculated flasks were incubated at each of the following temperatures $\left(4,23\right.$, and $37^{\circ} \mathrm{C}$, control temperature $\left.15^{\circ} \mathrm{C}\right)$ for 15 days. At the end of the trial, the contents of each flask were independently filtered through millipore filters ( $0.45 \mu \mathrm{m}$ pore size). The mycelium retained in the filter was removed with a spatula and deposited on aluminium foil (of known weight), and was weighed on an analytical balance, thereby obtaining the fresh weight (FW) of the mycelium. Finally, the foil containing the mycelium was deposited in a drying oven at $60^{\circ} \mathrm{C}$ for $48 \mathrm{hrs}$, and was then weighed, obtaining the dry weight (DW) of the mycelium. The increase of the mycelial weight (IMW) was determined by calculating the difference between the fresh weight and the dry weight (FW-DW).

The following criteria were used to select to the temperatures and the time of incubation: The average minimum winter temperature in Chile's Fourteenth Region is $4^{\circ} \mathrm{C}$. The average annual temperature in Chile's Fourteenth Region is $15^{\circ} \mathrm{C}$. The temperature at which the pure cultures of mycelial strains $\mathrm{D} 1$ and $\mathrm{D} 2$ of $D$. antarctica were obtained was $23^{\circ} \mathrm{C}$. The optimal temperature indicated by Miles and Chang (1997) for growth of some mesophilic fungi is $37^{\circ} \mathrm{C}$. The 15 -day incubation time was selected because the D1 and D2 colonies' maximum growth $(90 \mathrm{~mm})$ was determined to occur after 15 days of culture in previous studies.

\section{Determination of growth of the mycelial strains D1 and D2 of Descolea antarctica at different $\mathrm{pH}$ levels}

Flasks were prepared, in triplicate, each of which contained $200 \mathrm{ml}$ of MB $2 \%$ adjusted to different $\mathrm{pH}$ levels (from 1 to 14). As a control, three flasks were prepared as described above, but with $\mathrm{pH} 5.5$ (this $\mathrm{pH}$ was selected because it is the mean $\mathrm{pH}$ of volcanic soils from Chile's Fourteenth Region). Afterwards, each flask was inoculated with a 1.5 cm-diameter circle of agar of known weight with the appropriate strain's mycelium (the circles of agar with mycelium were obtained and weighed in the same way as indicated in step 1). The inoculated flasks were incubated at $23^{\circ} \mathrm{C}$ for 15 days. The increase of the mycelial weight (IMW) was determined in the same manner as indicated in step 1.

\section{Determination of the enzymatic activity of the mycelial strains D1 and D2 of Descolea antarctica at different $\mathrm{pH}$ levels and incubation temperatures}

The activity of the extracellular amylase enzymes, the phosphatases (acid and alkaline), and the cellulases were determined in triplicate for each of the filtrates that were obtained in the trials indicated in steps 1 and 2, following the procedures outlined hereafter.

Determination of amylases. These were performed following the protocol described in the Guía de Práctico de Conceptos y Técnicas de Biotecnología $I$ of the Universidad de Buenos Aires (Haim, 2000). One $\mathrm{ml}$ of filtrate and $1 \mathrm{ml}$ of starch solution $(10 \mathrm{mg} / \mathrm{ml})$ at $\mathrm{pH} 5.0$ (substrate) were deposited in a test tube. A control tube was also prepared with only the substrate. The tubes were incubated at $37^{\circ} \mathrm{C}$ for $1 \mathrm{hr}$ in a thermo regulated bath. In order to delay the reaction, $4.5 \mathrm{ml}$ of developing solution $\left(0.006 \% \mathrm{I}_{2} / \mathrm{IK}\right.$ in $\left.0.02 \mathrm{M} \mathrm{HCl}\right)$ was added to each tube, all of which were determined Absorbance $\left(\mathrm{A}^{\circ}\right)$ in spectrophotometer at $640 \mathrm{~nm}$, in comparison with the control. The difference in the measurements between the sample and the control would give the $\mathrm{A}^{\mathrm{o}}$ value, and this would be interpolated on the calibration curve. Using the relationship, $\mathrm{A}^{\mathrm{o}}=$ Calibration Factor $\cdot$ Concentration, one may obtain the concentration of starch $(\mathrm{mg} / \mathrm{ml})$, that was hydrolyzed by the amylases, which is equivalent to the quantity of enzymes that acted upon the substrate. The final concentration is expressed as a function of the dry weight of the fungal strain's mycelium ( $\mathrm{mg}$ glucose $/ \mathrm{ml} * \mathrm{~g}$ of mycelium * hr).

Determination of cellulases. By modified activity of carboxymethyl-cellulase (CM-cellulase) method, described by von Mersi and Shinner, 1990. The following were placed in a test tube: $1 \mathrm{ml}$ of the respective filtrate, to which was added $1 \mathrm{ml}$ of $\mathrm{pH} 5.5$ carboxymethylcellulose (CMC) solution (substrate), and $1 \mathrm{ml}$ of $2 \mathrm{M} \mathrm{pH} 5.5$ acetate buffer. The covered tubes were incubated at $50^{\circ} \mathrm{C}$ for $24 \mathrm{hrs}$ in a thermo regulated bath. After agitating the tube, $0.5 \mathrm{ml}$ of its contents was removed and deposited in another tube and was diluted with $20 \mathrm{ml}$ of distilled water. This tube was agitated, and $1 \mathrm{ml}$ of its diluted contents was extracted and deposited in a new tube, to which was added $1 \mathrm{ml}$ of reactive $\mathrm{A}\left(\mathrm{NaCO}_{3}\right.$ anhydrous, $\left.\mathrm{KCN}\right)$ and $1 \mathrm{ml}$ of reactive $\mathrm{B}\left(\mathrm{K}_{3}\left[\mathrm{Fe}(\mathrm{CN})_{6}\right]\right)$. The tubes were covered, and they were agitated and incubated at $100^{\circ} \mathrm{C}$ for $15 \mathrm{~min}$. After cooling to ambient temperature $\left(17^{\circ} \mathrm{C}\right)$ for $5 \mathrm{~min}, 5 \mathrm{ml}$ of reactive $\mathrm{C}$ (Dodecyl Sulfate Sodium salt (SDS) in $\mathrm{H}_{2} \mathrm{SO}_{4}$ conc. + $\mathrm{NH}_{4} \mathrm{Fe}(\mathrm{SO} 4)_{2}$ ) was added. Finally, one must wait for $1 \mathrm{hr}$ 
Table 2. Mean values of the increase of mycelial weights for strains D1 and D2 of Descolea antarctica cultured in malt broth at different $\mathrm{pH}$ levels.

\begin{tabular}{|c|c|c|c|}
\hline Strains & $\mathrm{pH}$ & DW (g) & IMW (g) \\
\hline & 4 & $0.11 \pm 0.0033 \mathrm{~h}$ & $0.06 \pm 0.0033 i$ \\
\hline & 5 & $0.31 \pm 0.0058 f$ & $0.26 \pm 0.0067 f$ \\
\hline & 6 & $0.29 \pm 0.0033 f$ & $0.24 \pm 0.0058 f$ \\
\hline & 7 & $1.02 \pm 0.0033 a$ & $0.97 \pm 0.0133 a$ \\
\hline \multirow[t]{9}{*}{ D1 } & 8 & $0.67 \pm 0.0058 b$ & $0.62 \pm 0.0088 c$ \\
\hline & 9 & $0.97 \pm 0.0067 \mathrm{a}$ & $0.92 \pm 0.0067 b$ \\
\hline & 10 & $0.53 \pm 0.0088 d$ & $0.48 \pm 0.008 d$ \\
\hline & 11 & $0.58 \pm 0.0033 c$ & $0.09 \pm 0.0033 i$ \\
\hline & Control $=\mathrm{pH} 5.5$ & $0.29 \pm 0.0033 f$ & $0.24 \pm 0.0033 f$ \\
\hline & 4 & $0.35 \pm 0.0058 \mathrm{e}$ & $0.34 \pm 0.0058 \mathrm{e}$ \\
\hline & 5 & $0.20 \pm 0.0033 \mathrm{~g}$ & $0.19 \pm 0.0033 \mathrm{~g}$ \\
\hline & 6 & $0.35 \pm 0.0033 \mathrm{e}$ & $0.34 \pm 0.0033 \mathrm{e}$ \\
\hline & 7 & $0.31 \pm 0.0033 f$ & $0.30 \pm 0.0033 \mathrm{e}$ \\
\hline \multirow[t]{5}{*}{ D2 } & 8 & $0.11 \pm 0.0067 \mathrm{~h}$ & $0.10 \pm 0.0033 \mathrm{hi}$ \\
\hline & 9 & $0.18 \pm 0.0058 \mathrm{~g}$ & $0.17 \pm 0.0067 \mathrm{~g}$ \\
\hline & 10 & $0.15 \pm 0.0067 \mathrm{gh}$ & $0.14 \pm 0.0058 \mathrm{~h}$ \\
\hline & 11 & $0.13 \pm 0.0100 \mathrm{~h}$ & $0.12 \pm 0.0100 \mathrm{~h}$ \\
\hline & Control $=\mathrm{pH} 5.5$ & $0.33 \pm 0.0033 \mathrm{e}$ & $0.32 \pm 0.0033 \mathrm{e}$ \\
\hline
\end{tabular}

DW: mycelial dry weight; IMW: increase of mycelial weight. Values with different letters in a column differ significantly from one another $(p \leq 0.05) . n=54$.

until colour develops (Berdines' blue) and one may determine the $A^{\circ}$ at $690 \mathrm{~nm}$. To obtain the concentration of cellulases, the value obtained by spectrophotometry (previously calculated as the difference between control and sample), is interpolated on the calibration curve and is multiplied by 40 (which corresponds to the dilution factor). The concentration of the enzyme $(\mathrm{mg} / \mathrm{ml})$ corresponds to the concentration of glucose produced by the cellulase complex upon the CMC. The final concentration is expressed as a function of the dry weight of the mycelium of the fungal strain (mgglucose/ml $* \mathrm{~g}$ of mycelium $* 24$ hrs).

Determination of acid and alkaline phosphatases. These were determined using the protocol described in Colvan et al. (2001). In two of four test tubes, $1 \mathrm{ml}$ of the respective filtrate was deposited. Two of the tubes were used to determine alkaline phosphatase $(\mathrm{pH} \mathrm{11,} \mathrm{a} \mathrm{sample} \mathrm{tube} \mathrm{and} \mathrm{a}$ control tube), and two tubes to determine acid phosphatase (pH 6.5). Afterwards, $4 \mathrm{ml}$ of modified universal buffer (modified universal buffer (MUB) $\mathrm{pH} 11$ or $\mathrm{pH}$ 6.5) was added to each tube, they were agitated, and $1 \mathrm{ml}$ of $p$ nitrophenyl (prepared in MUB $\mathrm{pH} 11$ or $\mathrm{pH} 6.5$ at a concentration of $8.4 \mu \mathrm{g} / \mathrm{ml}$ ) was added to each tube. The tubes were covered and incubated at $37^{\circ} \mathrm{C}$ for $1 \mathrm{hr}$ in a thermo regulated bath. After this, $1 \mathrm{ml}$ of $0.5 \mathrm{M} \mathrm{CaCl}_{2}$ and $4 \mathrm{ml}$ of $0.5 \mathrm{M} \mathrm{NaOH}$ were added to each tube, and the tubes were agitated. Finally, the contents of each tube was independently filtered, and the $\mathrm{A}^{\circ}$ at $400 \mathrm{~nm}$ was determined from the obtained filtrates. In parallel, the control tubes $(\mathrm{pH} 6.5$ and $\mathrm{pH}$ 11) were subjected to the same treatment, but fungal filtrate was not added to them. To obtain the concentration of acid and alkaline phosphatase, the value obtained by spectrophotometry (previously calculated as the difference between control and sample), is interpolated on the calibration curve. The final value corresponds to the concentration of the enzyme (mg of $p$-nitrophenol $/ \mathrm{ml}$ ). The final concentration is given as a function of the dry weight of the mycelium of the fungal strain (mg $p$-nitrophenol/ml $* \mathrm{~g}$ mycelium * hr). 
Table 3. Mean values of enzymatic activity levels for amylases, cellulases, and acid and alkaline phosphatases determined from malt broth filtrates after culturing strains D1 and D2 of Descolea antarctica at different temperatures.

\begin{tabular}{|c|c|c|c|c|c|}
\hline \multirow{2}{*}{ Strains } & $\begin{array}{c}\text { Temperature } \\
\left({ }^{\circ} \mathrm{C}\right)\end{array}$ & \multicolumn{4}{|c|}{ Extracellular enzymes } \\
\cline { 3 - 6 } & & A & B & C & D \\
\hline & 4 & $3.39 \pm 1.796 \mathrm{c}$ & $1.35 \pm 0.007 \mathrm{a}$ & $32.0 \pm 0.265 \mathrm{~b}$ & $7.51 \pm 0.027 \mathrm{~b}$ \\
\hline $\mathrm{D} 1$ & 23 & $0.19 \pm 0.000 \mathrm{c}$ & $0.04 \pm 0.009 \mathrm{~d}$ & $1.81 \pm 0.127 \mathrm{f}$ & $0.36 \pm 0.023 \mathrm{~d}$ \\
\hline & 37 & $5.65 \pm 3.262 \mathrm{c}$ & $0.12 \pm 0.012 \mathrm{c}$ & $58.1 \pm 0.033 \mathrm{a}$ & $10.1 \pm 0.281 \mathrm{a}$ \\
\hline & Control $15^{\circ} \mathrm{C}$ & $1.30 \pm 0.041 \mathrm{c}$ & $0.63 \pm 0.029 \mathrm{~b}$ & $11.1 \pm 0.437 \mathrm{~d}$ & $2.49 \pm 0.156 \mathrm{c}$ \\
\hline & 4 & $20.0 \pm 0.520 \mathrm{~b}$ & $0.63 \pm 0.023 \mathrm{~b}$ & $8.01 \pm 0.070 \mathrm{e}$ & $0.25 \pm 0.003 \mathrm{~d}$ \\
\hline $\mathrm{D} 2$ & 23 & $0.15 \pm 0.009 \mathrm{c}$ & $0.01 \pm 0.003 \mathrm{~d}$ & $0.56 \pm 0.000 \mathrm{~g}$ & $6.50 \pm 0.852 \mathrm{~b}$ \\
\hline & 37 & $57.2 \pm 3.262 \mathrm{a}$ & $0.71 \pm 0.033 \mathrm{~b}$ & $16.7 \pm 0.224 \mathrm{c}$ & $0.06 \pm 0.035 \mathrm{~d}$ \\
\hline & Control $15^{\circ} \mathrm{C}$ & $3.18 \pm 0.041 \mathrm{c}$ & $0.16 \pm 0.015 \mathrm{c}$ & $2.14 \pm 0.124 \mathrm{f}$ & $0.44 \pm 0.018 \mathrm{~d}$ \\
\hline
\end{tabular}

A: amylases (mg glucose $/ \mathrm{ml}^{*} \mathrm{~g}$ of mycelium ${ }^{*} \mathrm{hr}$ ).

B: cellulases (mg glucose $/ \mathrm{ml}^{*} \mathrm{~g}$ of mycelium * $24 \mathrm{hrs}$ ).

C: acid phosphatases ( $\mathrm{mg} p$-nitrophenol/ml ${ }^{*} \mathrm{~g}$ of mycelium * $\mathrm{hr}$ ).

$\mathrm{D}$ : alkaline phosphatases ( $\mathrm{mg} p$-nitrophenol $/ \mathrm{ml}{ }^{*} \mathrm{~g}$ of mycelium * $\mathrm{hr}$ ).

Values in a column with different letters differ significantly from one another $(p \leq 0.05) . n=24$.

The respective growth values and enzymatic activity levels of strains D1 and D2, determined at different temperatures and $\mathrm{pH}$ levels,were subjected to an analysis of variance (ANOVA) test with a 95\% confidence level. To better discriminate between treatments, a Tukey Test $(\mathrm{p}<0.05)$ was performed, using SPSS 11.0 Inc. (2001) statistical software.

\section{Determination of morphological parameters of Nothofagus obliqua plants cultivated under greenhouse and nursery conditions upon being artificially inoculated with mycelial strains of Descolea antarctica}

Hapludand ("trumao") soil ( $5.48 \mathrm{pH}$ in water, $5.45 \%$ total C, $0.36 \%$ total N, 15.0 C. N ratio, 37.6 ppm Olsen P, 3.04 $\mathrm{cmol}+/ \mathrm{kg}$ total content of interchangeable bases) was collected from the nursery at the Centro de Experimentación Forestal Universidad Austral de Chile(CEFOR) and was screened and sterilized in an autoclave $\left(121^{\circ} \mathrm{C}, 1 \mathrm{~atm}\right.$. of pressure for $\left.30 \mathrm{~min}\right)$.

Vermiculite was prepared in the following proportion. $500 \mathrm{~g}$ of vermiculite, with a $4-5 \mathrm{~mm}$ particle size, was mixed with 1.51 of MB $2 \% .300 \mathrm{~g}$ of the resulting mixture was put into each flask. These flasks were then sterilized in an autoclave $\left(121^{\circ} \mathrm{C}, 20 \mathrm{~min}\right)$, and afterwards each flask was inoculated with three circles of agar with mycelium from strain $\mathrm{D} 1$, and they were incubated at $23^{\circ} \mathrm{C}$ for 15 days. This same procedure was followed to culture strain D2 in flasks with vermiculite prepared as described above. As a control, this same procedure was followed again, but without fungal (D1 and D2) inoculation.

Seeds of $\boldsymbol{N}$. obliqua were pregerminated as follows. 1200 seeds were subjected to a flotation test in distilled water for $24 \mathrm{hrs}$. Afterwards, the viable seeds were soaked in $10 \%$ sodium hypochlorite for $10 \mathrm{~min}$ and were rinsed with distilled water. Thereafter, the seeds were left soaking in gibberelic acid for $24 \mathrm{hrs}$. Finally, to germinate the seeds, Petri plates were prepared with absorbent paper, and the seeds were placed in the plates and incubated at $23 \pm$ $2^{\circ} \mathrm{C}$ for 10 days. Afterwards, a layer of $70 \mathrm{~g}$ of the soil was deposited on trays that were $37.5 \mathrm{~cm}$ long x $24.5 \mathrm{~cm}$ wide and $7 \mathrm{~cm}$ deep, after which $70 \mathrm{~g}$ of vermiculite prepared as described above $(90 \%$ of which had been previously colonized by the mycelium of the D1 strain of $D$. Antarctica) was deposited on top of the first layer of soil in each tray. On top of this layer was deposited another layer of $70 \mathrm{~g}$ of the same soil described above same procedure was followed using vermiculite (prepared as described in step 4.3) colonized (90\%) by the D2 strain of D. Antarctica. The control was prepared using the same procedure, but using prepared vermiculite that was not inoculated with fungi (D1 and D2). Small holes were then pushed $1 \mathrm{~cm}$ 
deep into this soil. In this manner, 35 pre-germinated seeds of $N$. obliqua were sown in each of eight trays for each of the three treatments (24 trays total). The planted trays were maintained for two months in a greenhouse at a temperature that varied between 11.8 to $20^{\circ} \mathrm{C}$ and 70 to $80 \%$ humidity relative to the air. After completing the period of time in the greenhouse, the seedlings were transferred to the CEFOR nursery and transplanted in a $12.8 \mathrm{~m}$ long $\mathrm{x} 1.35 \mathrm{~m}$ wide bed (in nursery) in the same trumao soil that is described above (but which was not sterilized), spaced at a distance of $10 \mathrm{~cm}$ within rows, and $20 \mathrm{~cm}$ between rows, creating a planting density of 60 seedlings $/ \mathrm{m}^{2}$. A separating space of soil, $50 \mathrm{~cm}$ wide, was left between the control seedlings and those of each treatment. The seedlings remained in the bed for four months, during which they received homogenous watering and other horticultural care (weeding, application of pesticides to kill slugs and snails, etc.) needed for their optimal growth. At the end of the treatment trial, 60 randomly-selected seedlings were removed and evaluated in terms of the following morphological variables: diameter at root collar (DRC), height or length of stem, root length (which was measured with calipers from the collar to the farthest extremity of the plant's main central root), fresh and dry weight of stem and root. In addition, the following morphological indices were determined: stem length/root length ratio, DRC/stem length ratio, stem dry weight/root dry weight ratio, vigour quotient and Ritchie quality index. The obtained values were subjected to an analysis of variance (ANOVA) test with a $95 \%$ confidence level. To better discriminate between treatments, a Tukey Test $(\mathrm{p}<$ 0.05 ) was performed, using SPSS 11.0 Inc., 2001 statistical software. After finishing the greenhouse stage of this investigation, a microscopic study was made of the roots of 30 seedlings treated with $\mathrm{D} 1,30$ seedlings treated with $\mathrm{D} 2$, and 30 control seedlings. This microscopic study involved the qualitative determination (presence or absence) of the microscopic elements (hyphal sheath, terminal and intercalary capitate cystidia) indicated for $D$. antarctica by Palfner (2001), whose methodology was employed here. This same methodology was employed after finishing the nursery stage of this investigation, to evaluate the aforementioned microscopic elements in the roots of 30 seedlings treated with D1, 30 seedlings treated with D2, and 30 control seedlings.

\section{RESULTS}

Tables 1 and Table 2 show the mean values of the dry weights and the increase of mycelial weight of the mycelia of strains D1 and D2, respectively, of Descolea antarctica cultured in malt broth at different temperatures and $\mathrm{pH}$ levels.

In Table 1, one may observe that D1 and D2 show growth at different trial temperatures; for both strains, the greatest numerical increase in mycelial weight (IMW) was produced when they were cultured at $23^{\circ} \mathrm{C}$. The D1 strain exhibited numerically lower IMW values when it was cultured at 4 and $37^{\circ} \mathrm{C}$ in comparison with $\mathrm{D} 2$ and both strains cultured at $15^{\circ} \mathrm{C}$ (control temperature). The statistical comparison of the IMW values for D1 at the different trial temperatures determined that statistically significant differences exist, except for the IMW values determined at $4^{\circ} \mathrm{C}$ and $37^{\circ} \mathrm{C}$, which are statistically equal to the control. The statistical comparison of the IMW values for D2 at the different trial temperatures determined that statistically significant differences exist, except for the IMW values determined at $4^{\circ} \mathrm{C}$, which is statistically equal to the control. The statistical comparison of the IMW between D1 and D2, showed statistically significant differences exist between these two strains at each trial temperatures.

Growth in the two mycelial strains of D. Antarctica (D1 and D2) was not documented at the following pH levels: 1, $2,3,12,13$, and 14. In Table 2 one may observe that, for D1, numerical IMW values that are equal to or greater than those of the control $(0.24 \mathrm{~g})$ were determined at $\mathrm{pH}$ levels ranging from 5 to 10 , the highest IMW value of $0.97 \mathrm{~g}$ being at $\mathrm{pH}$ 7. For the $\mathrm{D} 2$ strain, numerical IMW values that are equal to or greater than those of the control $(0.32 \mathrm{~g})$ were determined when it was cultured in $\mathrm{MB}$ at $\mathrm{pH}$ levels between 4 and 6 . The statistical comparison of IMW values for $\mathrm{D} 1$ at the different trial $\mathrm{pH}$ levels with the IMW determined at the control $\mathrm{pH}$, established the existence of statistically significant differences, except for the IMW values determined at $\mathrm{pH}$ levels 5, 6 and control, which are statistically equal, and value determined at $\mathrm{pH} 4$ and 11 which is statistically squeal. The same analysis for D2 determined that there are statistically significant differences in IMW values, except for the IMW values at $\mathrm{pH}$ levels 4, 6 , and 7, which are statistically equal to the control. And values $\mathrm{pH}$ levels 8,10 , and 11 , which are statistically equal. And values $\mathrm{pH}$ levels 5 and 9 , which are statistically equal. The statistical comparison of the IMW between D1 and D2, showed statistically significant differences exist between these two strains at each trial $\mathrm{pH}$ level.

Table 3 provides the mean values of the enzymatic activities for amylases, cellulases, and acid and alkaline phosphatases evaluated in filtrates obtained from the MB, after culturing Descolea antarcticastrains D1 and D2 at different incubation temperatures for 15 days.

In Table 3, one can see the enzymatic activity levels of all of the investigated enzymes, independent of the incubation temperature and the strain. For D1, numerically higher values were measured for all of the enzymes in the filtrates obtained from the cultures made at $4^{\circ} \mathrm{C}$, in comparison to those found in the filtrates of the cultures made at the control temperature $\left(15^{\circ} \mathrm{C}\right)$. A similar tendency is observed for the enzymes in the filtrates obtained from the cultures developed at $37^{\circ} \mathrm{C}$, with the exception of the cellulases, whose value did not exceed that of the control. For the filtrates obtained from the D2 cultures made at $4^{\circ} \mathrm{C}$ and $37^{\circ} \mathrm{C}$, numerically higher values were found for the 
Table 4. Mean values of enzymatic activity levels for amylases, cellulases, and acid and alkaline phosphatases determined from malt broth filtrates after culturing strains D1 and D2 of Descolea antarctica at different pH levels.

\begin{tabular}{|c|c|c|c|c|c|}
\hline Strains & pH & \multicolumn{4}{|c|}{ Extracellular enzymes } \\
\hline & & A & B & C & D \\
\hline & 4 & $0.120 \pm 0.029 \mathrm{c}$ & $0.060 \pm 0.000 \mathrm{~b}$ & $1.720 \pm 0.012 \mathrm{a}$ & $1.770 \pm 0.000 \mathrm{a}$ \\
\hline & 5 & $0.245 \pm 0.026 \mathrm{~b}$ & $0.010 \pm 0.000 \mathrm{c}$ & $0.355 \pm 0.006 \mathrm{~d}$ & $0.320 \pm 0.018 \mathrm{e}$ \\
\hline & 6 & $0.680 \pm 0.006 \mathrm{a}$ & $0.015 \pm 0.003 \mathrm{c}$ & $0.355 \pm 0.006 \mathrm{~d}$ & $0.415 \pm 0.009 \mathrm{~d}$ \\
\hline & 7 & $0.050 \pm 0.006 \mathrm{~d}$ & $0.005 \pm 0.000 \mathrm{c}$ & $0.090 \pm 0.000 \mathrm{f}$ & $0.090 \pm 0.000 \mathrm{~g}$ \\
\hline $\mathrm{D} 1$ & 8 & $0.040 \pm 0.000 \mathrm{~d}$ & $0.008 \pm 0.000 \mathrm{c}$ & $0.150 \pm 0.006 \mathrm{ef}$ & $0.150 \pm 0.006 \mathrm{f}$ \\
\hline & 9 & $0.009 \pm 0.001 \mathrm{~d}$ & $0.005 \pm 0.000 \mathrm{c}$ & $0.105 \pm 0.003 \mathrm{f}$ & $0.115 \pm 0.003 \mathrm{~g}$ \\
\hline & 10 & $0.010 \pm 0.000 \mathrm{~d}$ & $0.009 \pm 0.000 \mathrm{c}$ & $0.150 \pm 0.000 \mathrm{ef}$ & $0.340 \pm 0.029 \mathrm{e}$ \\
\hline & 11 & $0.003 \pm 0.002 \mathrm{~d}$ & $0.058 \pm 0.002 \mathrm{~b}$ & $1.165 \pm 0.003 \mathrm{~b}$ & $1.360 \pm 0.012 \mathrm{~b}$ \\
\hline & $* \mathrm{pH} 5.5$ & $0.008 \pm 0.000 \mathrm{~d}$ & $0.004 \pm 0.000 \mathrm{c}$ & $0.350 \pm 0.023 \mathrm{~d}$ & $0.540 \pm 0.000 \mathrm{c}$ \\
\hline & 4 & $0.008 \pm 0.001 \mathrm{~d}$ & $0.019 \pm 0.009 \mathrm{c}$ & $0.015 \pm 0.003 \mathrm{~g}$ & $0.170 \pm 0.000 \mathrm{f}$ \\
\hline & 5 & $0.007 \pm 0.002 \mathrm{~d}$ & $0.110 \pm 0.006 \mathrm{a}$ & $0.180 \pm 0.006 \mathrm{e}$ & $0.030 \pm 0.000 \mathrm{~h}$ \\
\hline & 6 & $0.018 \pm 0.002 \mathrm{~d}$ & $0.020 \pm 0.006 \mathrm{c}$ & $0.135 \pm 0.003 \mathrm{ef}$ & $0.006 \pm 0.000 \mathrm{~h}$ \\
\hline & 7 & $0.017 \pm 0.001 \mathrm{~d}$ & $0.012 \pm 0.006 \mathrm{c}$ & $0.140 \pm 0.017 \mathrm{ef}$ & $0.010 \pm 0.000 \mathrm{~h}$ \\
\hline & 8 & $0.012 \pm 0.004 \mathrm{~d}$ & $0.021 \pm 0.012 \mathrm{c}$ & $0.740 \pm 0.000 \mathrm{c}$ & $0.015 \pm 0.003 \mathrm{~h}$ \\
\hline $\mathrm{D} 2$ & 9 & $0.290 \pm 0.007 \mathrm{~b}$ & $0.018 \pm 0.010 \mathrm{c}$ & $0.240 \pm 0.006 \mathrm{de}$ & $0.020 \pm 0.000 \mathrm{~h}$ \\
\hline & 10 & $0.120 \pm 0.006 \mathrm{c}$ & $0.021 \pm 0.001 \mathrm{c}$ & $0.305 \pm 0.032 \mathrm{~d}$ & $0.105 \pm 0.003 \mathrm{~g}$ \\
\hline & 11 & $0.040 \pm 0.006 \mathrm{~d}$ & $0.020 \pm 0.000 \mathrm{c}$ & $0.310 \pm 0.029 \mathrm{~d}$ & $0.420 \pm 0.006 \mathrm{~d}$ \\
\hline & $* \mathrm{pH} 5.5$ & $0.008 \pm 0.001 \mathrm{~d}$ & $0.010 \pm 0.000 \mathrm{c}$ & $0.285 \pm 0.009 \mathrm{~d}$ & $0.140 \pm 0.006 \mathrm{f}$ \\
\hline
\end{tabular}

${ }^{*} \mathrm{pH}: \mathrm{pH}$ control.

A: amylases (mg glucose $/ \mathrm{ml}^{*} \mathrm{~g}$ of mycelium * $\mathrm{hr}$ ).

B: cellulases (mg glucose $/ \mathrm{ml}^{*} \mathrm{~g}$ of mycelium * $24 \mathrm{hr}$ ).

C: acid phosphatases (mg p-nitrophenol $/ \mathrm{ml}^{*} \mathrm{~g}$ of mycelium * $\mathrm{hr}$ ).

$\mathrm{D}$ : alkaline phosphatases ( $\mathrm{mg} p$-nitrophenol $/ \mathrm{ml}^{*} \mathrm{~g}$ of mycelium ${ }^{*} \mathrm{hr}$ ).

Values in a column with different letters differ significantly from one another $(p \leq 0.05) \cdot n=54$.

activities of the amylases, cellulases, and acid phosphatases in comparison to those found in the filtrates of the cultures developed at $15^{\circ} \mathrm{C}$, and the filtrates made at $23^{\circ} \mathrm{C}$ showed the higher values for the alkaline phosphatases. Finally, the filtrates from the cultures of D1 and D2 made at $23^{\circ} \mathrm{C}$ showed the lowest values for the cellulases. Statistically significant differences were found with D1 for each enzyme at the distinct trial temperatures, with the exception of amylase which are statistically equal to the control. The same tendency was found with D2, with the a exception of nylases at 23 and $15^{\circ} \mathrm{C}$ (control), which are statistically equal; cellulases at 4 and $37^{\circ} \mathrm{C}$, which are statistically equal and alkaline phosphatases at 4,37 , and $15^{\circ} \mathrm{C}$, which are statistically equal. When the values of D1 and D2 are compared for the same enzymatic activity at the same temperature, statistically significant differences were found for amylases $\left(4\right.$ and $\left.37^{\circ} \mathrm{C}\right)$, cellulases $\left(4,15\right.$ and $\left.37^{\circ} \mathrm{C}\right)$, acid phosphatases $\left(4,15,23\right.$ and $\left.37^{\circ} \mathrm{C}\right)$ and alkaline phosphatases $\left(4,15,23\right.$ and $\left.37^{\circ} \mathrm{C}\right)$.

Table 4 provides the mean values of the enzymatic activities for amylases, cellulases, and acid and alkaline phosphatases evaluated in filtrates obtained from the $\mathrm{MB}$ after culturing Descolea antarcticastrains D1 and D2 at different incubationpH levels.

In Table 4, one can see the enzymatic activity levels of all of the investigated enzymes, independent of $\mathrm{pH}$ level and strain. For D1, numerically higher values were measured for cellulases, for acid and alkaline phosphatasesin the 
filtrates from the cultures made at $\mathrm{pH} 4$ and 11 , and for amylases in cultures at $\mathrm{pH} \mathrm{4,5}$ and 6 , in comparison to those found in the filtrates of cultures made at the control $\mathrm{pH}$ (5.5). For D2, numerically higher values were measured for amylases in the filtrates from the cultures made at $\mathrm{pH} 9$ and 10 , for cellulases in the filtrates of cultures made at $\mathrm{pH}$ 5 , for acid phosphatasesin the filtrates obtained from cultures made at $\mathrm{pH} 8$ and alkaline phosphatases filtrates at $\mathrm{pH} 11$. Statistically significant differences are found when comparing the values from D1 and D2, for the same enzymatic activity, for amylases $(\mathrm{pH} \mathrm{4}, 5,6,9$ and 10), cellulases ( $\mathrm{pH} 4,5$ and 11), acid phosphatases ( $\mathrm{pH} 4$ at 11 a exception $\mathrm{pH} 7$ and control $\mathrm{pH} 5.5$ ) and alkaline phosphatases ( $\mathrm{pH} 4$ at 11 and control $\mathrm{pH} 5.5$ ).

Table 5 and Table 6 respectively show the mean values of the morphological parameters, quotients, and indices established for control Nothofagus obliqua seedlings and for $N$. obliqua seedlings inoculated with the strains of Descolea antarctica. Figure 1 shows photographs of the control $N$. obliqua seedlings and $N$. obliqua seedlings inoculated with the strains of $D$. antarctica being studied.

Numerically higher values were obtained for the morphological parameters of the control $N$. obliqua seedlings that were transplanted to the nursery (Table 5), with the exception of the DRC, which was highest in seedlings treated with D2. For the morphological parameters (Table 5) and the morphological indices (Table 6), statistical analysis indicates that significant differences exist, between the control and the treatment with D1, for stem and root length, dry stem and root weight, DRC/SL, SDW/RDW, and Vigor quotient. For the morphological parameters (Table 5) and the morphological indices (Table 6), statistical analysis indicates that significant differences exist, between the control and the treatment with $\mathrm{D} 2$, for

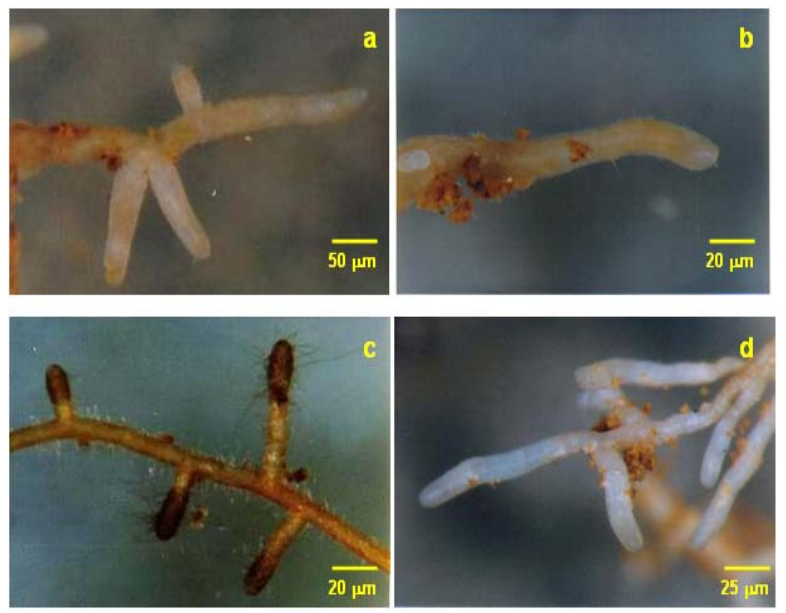

Figure 2. Roots obtained from Nothofagus obliqua seedlings that were grown in the nursery. (a-b) roots of plants treated with strain D2 of D. antarctica. (c) roots of control plants with mycorrhizae with morphology similar to that of Cenococcum geophilum. (d) roots of control plants with mycorrhizae with morphology similar to that of Laccaria laccata. stem and root length, DRC/SL, and Vigor quotient. On the other hand, comparing treatments D1 and D2, there are statistically significant differences in dry weight (Table 5), and also in the SDW/RDW relationship and the Ritchie indices (Table 6). As can be seen in Figure 1, when comparing the control plants with those treated with D1, no great differences can be observed in the total heights of the plants, the lengths and quantities of their roots, the lengths of their stems, etc. On the other hand, when comparing the control plants with those treated with D2, the most notable difference is in the quantities of roots. After finishing the greenhouse stage, a qualitative microscopic study was made of the roots of 30 seedlings treated with D1, 30 seedlings treated with D2, and 30 control seedlings. Microscopic elements (e.g., hyphal sheath, terminal and intercalary cystidia), such as those specified for $D$. antarctica by Palfner (2001), were found in the roots of 27 of 30 seedlings analyzed that were treated with $\mathrm{D} 1$, and in the roots of 29 of 30 seedlings that were treated with D2. No microscopic elements pertaining to $D$. antarctica or other mycorrhizal fungi were found in the roots of 30 analyzed control plants. These same elements were found in the roots of the seedlings treated with D1 (26 of 30 seedlings) and D2 (29 of 30 seedlings) after their time in the nursery. In addition, alter being grown in the nursery, the roots of the control plants were found to have been naturally colonized by mycorrhizal fungi distinct from $D$. antarctica; among others, these include Cenococcum geophilum and Laccaria laccata. These mycorrhizal fungi were not found in the roots of control seedlings grown in the greenhouse. The photographs in Figure 2 show roots of Nothofagus obliqua seedlings, grown in the nursery, that were treated with strain D2 of $D$. antarctica, and roots of control plants that had been naturally colonized by $C$. geophilum and $L$. laccata.

\section{DISCUSSION}

Deacon (1988) and, Miles and Chang (1997) pointed out that temperature is closely connected with microorganisms' metabolic reactions, and also with available water in liquid form and the alteration of macromolecules (nucleic acids and proteins, principally enzymes and permeases). Moreover, these authors indicate that, in the laboratory, the optimum range of temperatures for the growth of most soil fungi fluctuates between 25 and $40^{\circ} \mathrm{C}$, and that poor growth rates have been detected at temperatures between 0 and $5^{\circ} \mathrm{C}$. da Silva et al. (2005) pointed out that the scarce thermophilic fungi as Thermoascus auriantiacus, Humicola grisea var. thermoidea and Thiela terrestris growth between 30 to $65^{\circ} \mathrm{C}$. On the other hand, Cairney and Chambers (1999), have stated that most strains of ectomycorrhizal fungi display optimal growth between 23 and $25^{\circ} \mathrm{C}$, and very few grow at $4{ }^{\circ} \mathrm{C}$. For strains of the ectomycorrhizal Amanita caesaria, which is not phylogenetically related to $D$. antarctica, Daza et al. (2006) determined that optimal growth occurs at temperatures ranging from 24 to $28^{\circ} \mathrm{C}$. In laboratory studies made by Garrido (1988) with strains of the fungi Cenococcum 
geophilum and Paxillus statuum, which also are not phylogenetically related to $D$. antarctica, but which form ectomycorrhizae with Nothofagus spp., determined that, at $22^{\circ} \mathrm{C}$, the C. geophilum and P. statuum strains developed well. Alvarez et al. (2004) and Alvarez et al. (2005), in their research to locate and quantify phosphatase (SBP) activity, have employed cultures of $D$. antarctica that had been successfully cultured at $23^{\circ} \mathrm{C}$ before the trials were made. The results of the present study agree with what was indicated by the previously-cited authors, in that $D$. antarctica (D1 and D2) cultures grow best at $23^{\circ} \mathrm{C}$. In addition, for $\mathrm{D} 2$ cultivated at $37^{\circ} \mathrm{C}$, slightly superior growth (IMW $0.17 \mathrm{~g}$ ), in comparison with D1 (IMW $0.01 \mathrm{~g}$ ) and the control (IMW $0.05-0.08 \mathrm{~g}$ at $15^{\circ} \mathrm{C}$ ), was numerically determined to occur. Poor growth was found in the cultures of D1 and D2 made at $4^{\circ} \mathrm{C}$ (Table 1). In reference to the growth of mycelial strains of mycorrhizal fungi, Ferreira et al. (2005) determined that when the mycelial mass of Pisolithus sp. was exposed to a thermal shock $\left(42^{\circ} \mathrm{C}\right)$ for 30 min and later incubated at $28^{\circ} \mathrm{C}$ (optimal growth temperature), the synthesis of small heat shock proteins was observed as a response to the thermal stress. The D2 strain of $D$. antarctica possibly possesses a similar mechanism in order to be able to grow at $37^{\circ} \mathrm{C}$.

The results of the present investigation indicate that strain D2 of D. antarctica would be better adapted to temperature variations, which is important at the time that mycorrhizal colonization is achieved, because mycorrhized seedlings require a constant supply of nutrients $\left(\mathrm{PO}_{4}{ }^{2}, \mathrm{NO}_{3}\right.$ or $\mathrm{NH}_{4}$, and mineral salts) in order to grow, the transport of which to the host plant is facilitated by the mycelium of the mycorrhizal fungus. Moreover, in the nursery as well as in the field, the mycorrhized seedlings are exposed to daily thermal variations that change seasonally; therefore, in order to facilitate the plant's absorption of nutrients, the mycorrhizal fungal hyphae that make up the hyphal sheath must possess the capacity to adapt to these changes in temperature.

During their time in the nursery, the mycorrhized and nonmycorrhized Nothofagus seedlings are subjected to fertilization treatments, which alter the soil $\mathrm{pH}$ to a greater or lesser extent. In addition, the soil of the reforestation site might have an inadequate $\mathrm{pH}$. Therefore, laboratory studies of the growth, at different $\mathrm{pH}$ levels, of a fungus that has potential for use in mycorrhization, provide basic information about the fungus' possible performance. Deacon (1988) and Yamanaka (2003) indicate that many fungi, among them the mycorrhizal fungi, generally grow at $\mathrm{pH}$ levels from 4.5 to 8.0 under laboratory conditions. This is because various factors are affected by $\mathrm{pH}$; the most important of these include the enzymes, membrane permeability, and the degree of disassociation of the molecules into ions. This last aspect is important because, nutritionally, some molecules must be in a disassociated form, and others must not be in a disassociated form, in order to be absorbed by the fungal thallus and later to be utilized in metabolic processes. In the present study, no growth was observed for strains D1 and D2 of $D$. Antarctica at $\mathrm{pH}$ levels 1, 2, 3, 12,13, and 14; this is due to one or more of the reasons pointed out by Deacon (1988) and Yamanaka (2003). In Table 2, one may observe that, for strain D1, numerical IMW values that are equal to or greater than those of the control were found at $\mathrm{pH}$ levels ranging from 5 to 10 , but higher IMW values occurred within the range of $\mathrm{pH} 7$ to 10 , and the highest IMW value was found at $\mathrm{pH} 7$. For the D2 strain, numerical IMW values that are equal to or greater than those of the control occurred at $\mathrm{pH}$ levels between 4 and 6 . On the other hand, according to the molecular taxonomic studies made by Peinter et al. (2001), Descolea belongs to the Cortinariacea Family, and is phylogenetically related to other mycorrhizal fungi, like Hebeloma. Accounting for this background, if one compares the results obtained for D1 and D2 in a study made by Yamanaka (2003), who determined the effect of $\mathrm{pH}$ on the growth of saprotrophic and ectomycorrhizal ammonia fungi, this author points out that the culture of strains of the ectomycorrhizal fungi Hebeloma vinosophyllum and $H$. radicosoides showed optimum growth at $\mathrm{pH} 5$ or 6 , which agrees with what was established for strain $\mathrm{D} 2$ of $D$. antarctica at $\mathrm{pH} 6$, but not at $\mathrm{pH}$ 5. Moreover, this author indicates that $H$. vinosophyllum and $H$. radicosoides survive in soil as vegetative hyphae at neutral to alkaline $\mathrm{pH}$ values, and they only form their fruiting bodies at $\mathrm{pH} 5$ or 6 . This author also points out that the studied saprotrophic species grew well at $\mathrm{pH} 7$ or 8 , which is similar to the performance of the D1 strain of $D$. antarctica at $\mathrm{pH} 7$, but not at $\mathrm{pH} 8$. On the other hand, knowing that $D$. antarctica is a facultative ectomycorrhizal fungus, it follows that the superior growth at $\mathrm{pH} 7$ of strain D1 resembles that of a saprophytic fungus, and the growth of strain D2 at $\mathrm{pH} 6$ is like that of an ectomycorrhizal fungus. The inferior growth of strain $\mathrm{D} 1$ at $\mathrm{pH} 8$, and of strain $\mathrm{D} 2$ at $\mathrm{pH} 5$, would be explained because, according to (Deacon, 1988), every fungal strain is a genetically distinct individual that possesses its own distinctive, unique genes, as well as other genes which it has in common with other strains of the same species. These distinctive genes are expressed or silenced under certain circumstances, such as a specific $\mathrm{pH}$ point, temperature, nutrient, etc. According to what has been previously indicated, both strains of $D$. antarctica are able to grow within a broad $\mathrm{pH}$ range $(\mathrm{pH} 4$ 11 ), and therefore could be utilized as inoculants for Nothofagus seedlings used to reforest sites with soils that possess unsuitable $\mathrm{pH}$ levels.

As was indicated in previous paragraphs, $23^{\circ} \mathrm{C}$ is the optimum temperature for the growth of D1 and D2. However, it is well known that many microorganisms, among them the fungi, possess numerous biochemical mechanisms that enable them to survive at temperatures other than their optima. These biochemical mechanisms include higher levels of exoenzyme production and excretion in order to assure the uptake of nutrients (Atlas and Bartha, 2002). In the present study (Table 3), the higher values registered at 4 and $37^{\circ} \mathrm{C}$, in comparison with those registered at $23^{\circ} \mathrm{C}$, for the majority of the enzymes (except 
Table 5. Mean values established for morphological parameters obtained from control Nothofagus obliqua seedlings, and from $N$. obliqua seedlings inoculated with strains of Descolea antarctica.

\begin{tabular}{|c|c|c|c|c|c|}
\hline \multirow[t]{3}{*}{ Treatment } & \multicolumn{5}{|c|}{ Morphological parameters } \\
\hline & \multirow{2}{*}{$\begin{array}{l}\text { DRC } \\
(\mathrm{mm})\end{array}$} & \multicolumn{2}{|c|}{ Length (cm) } & \multicolumn{2}{|c|}{ Dry weight (g) } \\
\hline & & Stem & Root & Stem & Root \\
\hline Control $(\mathrm{T})$ & $2.7 a \pm 0.766$ & $35.67 \mathrm{a} \pm 7.532$ & $22.67 \mathrm{a} \pm 3.884$ & $1.49 a \pm 0.718$ & $0.51 \mathrm{a} \pm 0.276$ \\
\hline D1 & $2.8 \mathrm{ac} \pm 0.576$ & $30.33 b \pm 5.417$ & $19.55 b \pm 3.291$ & $1.06 b \pm 0.355$ & $0.39 b \pm 0128$ \\
\hline D2 & $3.1 \mathrm{bc} \pm 0.000$ & $32.29 b \pm 7.586$ & $19.37 b \pm 4.267$ & $1.44 a \pm 0.660$ & $0.45 a \pm 0.197$ \\
\hline
\end{tabular}

D1: seedlings inoculated with the D1 strain of $D$. antarctica. D2: seedlings inoculated with the D2 strain of $D$. antarctica. DRC: diameter at root collar.

The values correspond to the mean of $n=60$ seedlings per treatment.

Values with different letters in the column differ significantly from one another (Tukey-HSD test $p \leq 0.05$ ).

for alkaline phosphatase from strain D2) would be consequences of both strains' adaptive responses to extreme temperatures. For example, Tibbett et al. (1999) determined that, for different strains of Hebeloma spp., low temperatures $\left(0-6^{\circ} \mathrm{C}\right)$ induce higher proteolytic activity and therefore grant the fungus a potential capacity to acquire nutrients at temperatures as low as $0^{\circ} \mathrm{C}$. Regarding the cellulases, the results of this study (Table 3) are similar to those of Redlak et al. (2001) for different strains of Hebeloma crustuliniforme; these authors found low levels of cellulase activity in strains of $\mathrm{H}$. crustuliniforme compared with what is documented for saprophytic and phytopathogenic fungi. These authors point out that these low activity levels could be explained in that mycorrhizal fungi nourish themselves principally with simple compounds that they encounter in exudates from the roots of plants with which the fungi have formed mycorrhizal associations. This would also explain the high values recorded in the present study for the amylases, because one can find amylose and amylopectin in the roots' exudates, and in the starch of dead plant cells from the growing root tip. One may also encounter compounds similar to starch, all of which are easily degraded, in these dead plant cells. On the other hand, Wright et al. (1998) pointed out that in plant/fungus associations, sucrolytic enzymes, invertase and sucrose synthetase have been detected. These enzymes have been strongly implicated in the diversion of carbohydrates to the mycobiont, and they would be synthesized by the mycobiont.

In searching the literature, no studies of phosphatases (acid and alkaline) were found that were performed under the same experimental conditions, and with fungal strains $D$. antarctica, that permit the acceptance or rejection of the results obtained in the present study. The closest are those of Alvarez et al. (2004) and Alvarez et al. (2005), who used a confocal laser-scanning microscope for the first time to localize and quantify superficial phosphatase (SBP) activity in roots of $N$. obliqua mycorrhized with the fungus $D$. antarctica. The authors demonstrated the capacity of the hyphae from the hyphal sheath of $D$. antarctica to induce SBP activity and to translocate phosphate to the roots of $N$. obliqua. The results obtained in the present study for phosphatase activities determined from the filtrates of the cultures at $23^{\circ} \mathrm{C}$ are in agreement with those of Alvarez et al. (2004) and Alvarez et al. (2005) only in terms of the amount of phosphatase quantified. The results obtained at low temperatures for phosphatases are similar to those of Tibbett et al. (1998), who determined the effects of temperature and inorganic phosphorus supply on growth and phosphatase production in arctic and temperate strains of ectomycorrhizal Hebeloma spp. in axenic culture. These authors indicate that acid phosphatase production by 12 Hebeloma strains was usually depressed when inorganic phosphorus in the medium was limited, but appeared to be constitutive in some strains. At low temperatures $\left(<12^{\circ} \mathrm{C}\right)$, arctic strains produced more extracellular and wall-bound acid phosphatase, yet grew more slowly than temperate strains. Low growth rates in arctic strains may be a physiological response to cold whereby resources are diverted into carbohydrate accumulation for cryoprotection. At near freezing temperatures, increased extracellular phosphatase production may compensate for a loss of enzyme activity at low temperatures, and may serve to hydrolyze organic phosphorus in frozen soil.

With respect to the enzymatic activity at different $\mathrm{pH}$ levels, Table 4 displays these results for all of the assayed enzymes, independent of the filtrate analyzed and its $\mathrm{pH}$. These numerical results suggest that the amylases of D1 and $\mathrm{D} 2$ behave differently depending on the $\mathrm{pH}$, or that both strains are capable of excreting different kinds of 
Table 6. Average values of relationships, quotients, and indices established for control Nothofagus obliqua seedlings, and for $N$. obliqua seedlings inoculated with strains of Descolea antarctica.

\begin{tabular}{|c|c|c|c|c|c|}
\hline \multirow[t]{3}{*}{ Treatment } & \multicolumn{5}{|c|}{ Morphological indices } \\
\hline & \multicolumn{3}{|c|}{ Ratio } & \multicolumn{2}{|c|}{ Quotient and Index } \\
\hline & SL/RL & DRC/SL & SDW/RDW & Vigor quotient & Ritchie Index \\
\hline Control $(\mathrm{T})$ & $1.61 \mathrm{a} \pm 0.423$ & 1: $137 \mathrm{a} \pm 28.830$ & $3.07 \mathrm{a} \pm 0.822$ & $13.71 \mathrm{a} \pm 2.873$ & $0.015 a b \pm 0.009$ \\
\hline D1 & $1.58 a \pm 0.328$ & 1: $111 b \pm 22.449$ & $2.84 b \pm 0.782$ & $11.13 b \pm 2.242$ & $0.013 b \pm 0.005$ \\
\hline D2 & $1.74 a \pm 0.533$ & 1: $108 b \pm 19.779$ & $3.20 a \pm 0.731$ & $10.76 b \pm 1.973$ & $0.017 a \pm 0.008$ \\
\hline
\end{tabular}

D1: seedlings inoculated with the D1 strain of $D$. antarctica.

D2: seedlings inoculated with the D2 strain of $D$. antarctica. SL/RL: stem length/root length.

DRC/SL: diameter at root collar/stem length. SDW/RDW: stem dry weight/root dry weight.

The values correspond to the mean of $n=60$ seedlings per treatment.

Values with different letters in the column differ significantly from one another (Tukey-HSD test $p \leq 0.05$ ).

amylases, because D1's amylases have higher levels of activity at an acidic $\mathrm{pH}$ (e.g., $\mathrm{pH}$ 6.0), and are more sensitive to basic $\mathrm{pH}$ levels, while D2's amylases have higher levels of activity at a basic $\mathrm{pH}$ (e.g., $\mathrm{pH} 9.0)$ and are more sensitive to acidic $\mathrm{pH}$ levels. It has been determined that the enzymatic activities of different amylases occur at $\mathrm{pH}$ levels that range from 4.5 to 8.5 (Tabatabai, 1994). In a study made by Kusuda et al. (2003), an a-amylase was purified from cultures of the ectomycorrhizal Tricholoma matsutake (which is not phylogenetically related to Descolea) made at $24^{\circ} \mathrm{C}$. This enzyme is active at $\mathrm{pH} 6$, and is stable within the broad range of $\mathrm{pH}$ levels from 4 to 10 . The cellulases of both strains display a tendency to greater enzymatic activity levels at acidic $\mathrm{pH}$ levels. However, for cellulases from $\mathrm{D} 2$ at basic $\mathrm{pH}$ levels, values were registered similar to those determined at acidic $\mathrm{pH}$ levels. It is well known that cellulolytic activity is carried out more effectively, in saprophytic as well as mycorrhizal fungal strains, within the range of acidic $\mathrm{pH}$ values from 5 to 6.5 . In this sense, da Silva et al. (2005) determined that the optimum $\mathrm{pH}$ for the activity of crude CMCase in strains of the saprophytic fungus T. aurantiacus, is 5.5 . At $\mathrm{pH} 4.0$, no enzymatic activity was detected. Yamanaka (2003) pointed out that cellulolytic enzymes of ectomycorrhizal fungi (LP) display optimal enzymatic activity within the $\mathrm{pH}$ range 5.5 - 6.8, and are more stable at acidic $\mathrm{pH}$ levels than at alkaline ones. Redlak et al. (2001) indicate that, for strains of the mycorrhizal fungi Hebeloma crustuliniforme higher cellulase activity was found at acidic $\mathrm{pH}$ levels (from 5.0 to 5.5). These aforementioned authors' results agree with what was determined in the present study for D1's cellulases, but not with what was determined for D2's cellulases. In this sense, one could hypothesize that D2's cellulases could be more stable within a broader range of $\mathrm{pH}$ values, or that $\mathrm{D} 2$ may possess cellulases that are active at different $\mathrm{pH}$ levels, but further investigation is necessary to demonstrate this.

With respect to the phosphatases, if one examines Table 4, one observes that, within the most acidic and basic ranges of $\mathrm{pH}$ values, higher activity levels have been established for acid and alkaline phosphatases. These activity level values do not correspond to those phosphatases that are evaluated at their respective $\mathrm{pH}$ levels, for example, higher values for alkaline phosphatases were measured from filtrates from the D1 cultures made at $\mathrm{pH}$ levels 4.0, 5.0, and 6.0, when one would expect higher values to be recorded at a basic $\mathrm{pH}$ level. The same can be observed with the higher values for acid phosphatase that were measured from the filtrates from the D2 cultures made at $\mathrm{pH}$ levels from 8.0 to 11 . It is possible to explain these results by arguing that the modified universal buffer (MUB $\mathrm{pH} 11$ or $\mathrm{pH} 6.5$ ) and the MUB utilized to prepare the substrate were unable to modify the $\mathrm{pH}$ levels of the extremely acidic or alkaline filtrates. On the other hand, in the only similar study made by Alvarez et al. (2004), in which the activity of the acid phosphatase in D. antarctica was determined, the authors point out that the superficial acid phosphatase (SBP) of D. antarctica presents better activity at $\mathrm{pH}$ 5.0. In the same study, these authors also found that the SBP of other ectomycorrhizal fungal associates of $N$. obliqua, i.e., of P. involutus, has greater activity at $\mathrm{pH}$ levels $3.5,4.0,5.0$, and 6.0, and that the SBP

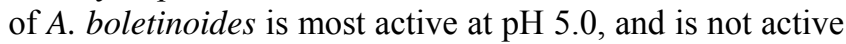
at pH 7.0. In another study, Kong et al. (1998) investigated the responses of different mycorrhizal fungal associates of Pinus massoniana (among others, Cortinarius russus, which is phylogenetically related to Descolea) to artificial acid rain in the laboratory, establishing that acid rain of $\mathrm{pH}$ 
4.5 stimulates mycorrhization and acid phosphatase activity, and that acid rain of $\mathrm{pH} 3.0$ inhibits the activity of acid phosphatase. In reference to alkaline phosphatase, no studies, of $D$. antarctica or other phylogenetically related fungi,were found, that were made under the same conditions under which the present investigation was carried out, that permit the acceptance or rejection of the results presented in Table 4. For other kinds of mycorrhizal fungi, Joner et al. (2000), indicate that alkaline phosphatase is scarce and that its activity is expressed under adverse conditions, such as those to which the extra-radical arbuscular mycorrhizal hyphae (ERM) are exposed.

On the other hand, if one compares the numerical values of the enzymatic activity levels established for the filtrates from different temperatures (Table 3) with those obtained from the same enzymes in the filtrates from different $\mathrm{pH}$ levels (Table 4), one will observe higher values recorded for all of the enzymes in the filtrates from different temperatures. This agrees with what was noted by Tabatabai (1994), who pointed out that $\mathrm{pH}$ produces greater alterations in enzymatic activity than temperature does, because changes in $\mathrm{pH}$ influence enzymes, substrates, and cofactors, and they alter ionization and solubility; variation in these last two parameters influences the rate of the catalyzed reaction, since enzymes, being proteins, exhibit marked changes in ionization with fluctuations in $\mathrm{pH}$. In this way, every enzyme has a $\mathrm{pH}$ value at which its reaction rate is optimal, and therefore enzymes are more stable within the neighbourhoods of their optimal $\mathrm{pH}$ levels, and they are irreversibly denatured at extremely acidic or basic $\mathrm{pH}$ levels.

Once again, it must be pointed out that, according to the results of the enzymatic activity levels established from the filtrates from different temperatures and different $\mathrm{pH}$ levels, both strains D1 and D2 of D. antarctica have a broad range of enzymes that would permit them to survive the variations in temperature and $\mathrm{pH}$ that eventually could occur during the formation of mycorrhizal associations, and they could also facilitate the absorption of nutrients by Nothofagus seedlings, in the nursery as well as in the greenhouse, where the plants are exposed to different temperatures (diurnal, nocturnal, seasonal), and soil $\mathrm{pH}$ levels that vary according to the application of amendments (mainly nitrogenous fertilizers).

In reference to the inoculation of $N$. obliqua seedlings in the greenhouse with strains D1 and D2 of $D$. antarctica,numerically higher values were obtained for the morphological parameters of the control $N$. obliqua seedlings that were transplanted to the nursery (Table 5), with the exception of the DRC, which was highest in seedlings treated with D2. Moreover, Figure 1 shows that the $N$. obliqua seedlings treated with D2 present extensive radical systems of high biomass. These two parameters (DRC and extensive radical systems of high biomass) agree with what was indicated by Duñabeitia et al. (2004), who pointed out that one of the most important morphological parameters is the DRC. These authors indicate that seedlings with higher DRC values are generally associated with more extensive aerial and radical systems of greater biomass. They are also associated with higher amounts of chlorophyll and carbohydrates, which confer an acceptable survival rate to the seedlings growing in the field. Concerning the numerical values for the morphological parameters (Table 5) of $N$. obliqua seedlings inoculated with D1, they are lower than those determined for the control. A similar tendency is observed in the morphological indices (Table 6). These results would indicate that inoculation with strain D1 of D. antarctica was not as effective as was expected. Concerning the numerical values for the morphological parameters (Table 5) of $N$. obliqua seedlings inoculated with D1, they are lower than those determined for $N$. obliqua seedlings inoculated with D2. A similar tendency is observed in the morphological indices (Table 6), with the exception of the $\mathrm{DRC} / \mathrm{SL}$ and the Vigor index. These results would indicate that inoculation with strain D2 of D. antarctica is more effective. The morphological differences are much more evident in Figure 1.

In a similar study carried out by Godoy et al. (1995), $N$. alpina seedlings were inoculated with mycorrhizal fungi other than $D$. antarctica, but the $N$. alpina plants were grown in trumao soil. These authors determined that the DRC varied between $3.56 \mathrm{~mm}$, for $N$. alpina seedlings inoculated with Amanita sp., and $4.46 \mathrm{~mm}$ for the best treatment (inoculation with Suillus sp.). The results obtained with Amanita sp. are similar to those obtained in the present study for $N$. obliqua seedlings inoculated with D2, and they are numerically superior to those obtained for control $N$. obliqua seedlings and for $N$. obliqua seedlings inoculated with D1. In reference to total length (LT) and total dry weight (TWD), the seedlings inoculated with D2 show a similar tendency to that determined by Godoy et al. (1995) for N. alpina seedlings inoculated with Suillus sp., (LT $44.46 \mathrm{~cm}$ and TWD $=1.49 \mathrm{~g}$ ). The results for the seedlings inoculated with D1 are similar to those recorded by Carrillo et al. (1994) for $N$. obliqua seedlings grown in trumao soil that were inoculated with the ectomycorrhizal fungi, P. tinctorius (LT 48,6 cm and TWD $1.43 \mathrm{~g}$ ) and $L$. laccata (LT $45.7 \mathrm{~cm}$ and TWD $1.48 \mathrm{~g}$ ). Results for the morphological indices (Table 6) are similar to those obtained by the aforementioned authors.

In the present study, the results show that, when the treatments of seedlings with strains D1 and D2 are compared, the latter appears to be the better inoculant for $N$. obliqua seedlings, although the $N$. obliqua seedlings inoculated with D2 do not yield higher values than the control seedlings for a number of the parameters and some of the evaluated morphological indices. This is explained in that the control seedlings form mycorrhizal associations naturally in the nursery with fungi other than $D$. antarctica, among others, C. geophilum and L. laccata (Figure 2). This result, which appears to be negative, would permit the 
establishment of the degrees of competitiveness of $D$. antarctica and the other mycorrhizal fungal species, because no microscopic structures indicative of $C$. geophilum and $L$. laccata were found in the $N$. oblique seedlings inoculated with D1 and D2. It is also important to point out that the addition of fertilizer is not necessary during the formation of mycorrhizal associations between the $N$. obliqua seedlings and the D1 and D2 strains (the $N$. obliqua seedlings were only periodically watered while being grown; no fertilizer was added). Fertilization can result in environmental repercussions and budgetary complications. As was previously indicated, there should also be good root development in $N$. obliqua seedlings inoculated with D2; these plants could have become more firmly rooted in the soil, and their roots could have explored a greater volume of soil, which is extremely important in soils that have experienced some degree of degradation and are low in nutrients. Finally, the overall results of the present study show that, principally with inoculation with D2, suitable $N$. obliqua seedlings may be obtained for use in reforestation or in the establishment of plantations of this arboreal species in sites that have or have not been anthropogenically altered to some degree.

\section{REFERENCES}

ALVAREZ, M.; GODOY, R.; HEYSER, W. and HÄRTEL, S. Surface-bound phosphatase activity in living hyphase of ectomycorrhizae fungi of Nothofagus obliqua. Mycologia, May 2004, vol. 96, no. 3, p. 479-487.

ALVAREZ, M.; GODOY, R.; HEYSER W. and HÄRTEL, S. Anatomical-physiological determination of surface bound phosphatase activity in ectomycorrhizae of Nothofagus obliqua. Soil Biology and Biochemistry, January 2005, vol. 37, no. 1, p. 125-132.

ATLAS, Ronald and BARTHA, Richard. Ecología microbiana y Microbiología ambiental. Madrid - España; Pearson Educación S.A, 2002. 696 p. ISBN 84-7829-039-7.

CARDOSO, I. and KUYPER, T. Mycorrhizas and tropical soil fertility. Agriculture Ecosystems and Environment, 2006, vol. 116 , no. $1 / 2$, p. $72-84$.

CAIRNEY, John and CHAMBERS, Susan. Ectomycorrhizal Fungi, key genera in profile. Berlin Germany; Springer - Verlag, 1999. 369 p. ISBN 3-54065609-X.

CARRILLO, R.; PEREDO, H.; VIVES, I. and GODOY, R. Inoculación con hongos ectomicorricicos en plantas de Nothofagus obliqua (Mirb.) Oerst. In: Congreso Latinoamericano de Botánica. $\left(6^{\circ}, 2^{\text {nd }}-8^{\text {th }}, 1994\right.$, Mar del Plata, Argentina). Libro de resúmenes sesiones técnicas VI Congreso Latinoamericano de Botánica. Editorial Producción Gráfica, Servicios Gráficos. Buenos Aires, Argentina, 1994. p. 668.
CLEMMENSEN, K. and MICHELSEN, A. Integrated long-term responses of an arctic-alpine willow and associated ectomycorrhizal fungi to an altered environment. Canadian Journal of Botany, 2006, vol. 84, no. 5, p. 831843.

COLVAN, S.; SYERS, K. and O'DONNELL, A. Effect of long-term fertiliser use on acid and alkaline phosphomonoesterase and phosphodiesterase activities in managed grassland. Biology and fertility of soils, 2001, vol. 34 , p. $258-263$.

CORREA, A.; STRASSER, R. and MARTINS-LOUCAO, M. Are mycorrhiza always beneficial? Plant and Soil, January 2006, vol. 279, no. 1/2, p. 65-73.

DA SILVA, R.; LAGO, E.; MERHEB, C.; MACCHIONE, M.; PARK, Y. and GOMES, E. Production of xylanase and CMCasa on solid state fermentation in different residues by Thermoascus aurantiacus Miehe. Brazilian Journal of Microbiology, 2005, vol. 36, no. 3, p. 235-241.

DAZA, A.; MANJON, J.; CAMACHO, M.; ROMERO, O.; AGUILERA, A. and SANTAMARIA, C. Effect of carbon and nitrogen sources, $\mathrm{pH}$ and temperature on in vitro culture of several isolates of Amanita caesaria (Scop.: Fr.) Pers. Mycorrhiza, 2006, vol. 16, no. 2, p. 133-136.

DEACON, J.W. Introducción a la Micología Moderna. Mexico D.F; Editorial Limusa S.A., 1988. 350 p. ISBN 0632-01156-4.

DUÑABEITIA, M.; RODRIGUEZ, N.; SALCEDO, I. and SARRIONANDIA, E. Field mycorrhization and its influence on the establishment and development of the seedlings in a broadleaf plantation on the Basque country. Forest Ecology and Management, 2004, vol. 195, no. 1/2, p. 129-139.

ECHEVERRIA，C.; COOMES，D.; SALAS，J.; REYBENAYAS, J.; LARA, A. and NEWTON, A. Rapid deforestation and fragmentation of Chilean temperate forests. Biological Conservation, July 2006, vol. 130, no. 4, p. 481-494.

FERREIRA, A.; TOTOLA, M.; KASUYA, M.; ARAUJO, E. and BORGES, A. Small heat shock proteins in the development of thermotolerance in Pisolithus sp. Journal of Thermal Biology, December 2005, vol. 30, no. 8, p. 595602 .

GARRIDO, Norberto. Agaricales s.l und ihre in den Nothofagus - wäldern mitelchiles. Berlin - Germany; J. Cramer, Bibliotheca Mycologica Band 120. 1988. 523 p. ISBN 3-443-59021-7.

GODOY, R., CARRILlO, R. and von PEREDO, H. Ökologische und experimentelle arbeiten ubre mykorrhiza in naturwäldern südchiles. Verhandlungen der Gesellschaft 
für Ökologie Band 24. 1995. p. 619-622. ISBN 3-43725058-2.

GODOY, R.; PALFNER, G.; OYARZÚN, C. and DONOSO, P. Mycorrhizal studies in pristine forest ecosystems of southern Chile. In: $5^{\text {th }}$ International Conference Mycorrhiza: Mycorrhiza for Science and Society. $\left(23^{\text {rd }}-27^{\text {th }}\right.$ July, 2006, Granada, Spain). Abstracts, 2006. p. 283.

HAIM, L. Guía de prácticos. Conceptos y técnicas de Biotecnología I. Departamento de Fisiología, Biología Molecular y Celular. Facultad de Ciencias Exactas y Naturales. Universidad de Buenos Aires. Argentina, March 2000 (cited 2 December 2003). Available from Internet: www.fbmc.fcen.uba.ar/cytdb1gtp/amilasagtp.doc.

HEADS, M. Penbiogeography of Nothofagus (Nothofagaceae): analysis or the main species massings. Journal of Biogeography, 2006, vol. 33, no. 6, p. 10661075.

JONER, E. and JOHANSEN, A. Phosphatase activity of external hyphae of two arbuscular mycorrhizal fungi. Mycological Research, 2000, vol. 104, no. 1, p. 81-86.

JONER, E.; VAN AARLE, I. and VOSATKA, M. Phosphatase activity of extra-radical arbuscular mycorrhizal hyphae: A review. Plant and Soil, 2000, vol. 226, no. 2, p. 199-210.

KONG, F.; ZHOU, C. and LIU, Y. Biochemical and cytological responses of ectomycorrhizae in Pinus massoniana to artificial acid rain. Chemosphere, 1998, vol. 37, no. 1, p. 179-181.

KUSUDA, M.; NAGAI, M.; HUR, T.; UEDA, M. and TERASHITA, T. Purification and some properties of $\alpha-$ amylase from an ectomycorrhizal fungus, Tricholoma matsutake. Mycoscience, 2003, vol. 44, p. 311-317.

MILES, Philip and CHANG, Shu-ting. Mushroom Biology. New Jersey, USA. World Scientific Publishing Co. Pte. Ltd. 1997. 194 p. ISBN 981-02-2877-5.

MOLINA, R. and PALMER, J. Isolation, maintenance and pure manipulation of ectomycorrhizal fungi. In: SCHENK, N.C. ed. Methods and principles of mycorrhizal research. Florida, USA. The American Phytopathological Society, 1982, p. 115-129.

PALFNER, Götz. Taxonomische studien an ektomykorrhizen aus den Nothofagus-wäldern mittelsüdchiles. Berlin, Germany; J. Cramer, Bibliotheca Mycologica Band 190. 2001. 243 p. ISBN 3-443-59092-6.

PEINTNER, U.; BOUGHER, N.; CASTELLANO, M.; MONCALVO, J.; MOSER, M.; TRAPPE, J. and VILGALYS, R. Multiple origins of sequestrate fungi related to Cortinarius (Cortinariaceae). American Journal of Botany, 2001, vol. 88, p. 2168-2179.

PERI, P.; GARGAGLIONE, V. and MARTINEZ, G. Dynamics above and below ground biomass and nutrient accumulation in a age sequence of Nothofagus antarctica forest of southem Patagonia. Forest Ecology and Management, 2006, vol. 233, no. 1, p. 85-89.

REDLAK, K.; DAHM, H.; CIESIELSKA, A. and STRZELCYK. E. Enzymatic activity of ectendomycorrhizal fungi. Biology and Fertility of Soils, 2001, vol. 33, p. 83-90.

SALAS, C.; LEMAY, V.; NUÑEZ, P.; PACHECO, P. and ESPINOSA, A. Spatial patters in an old grow Nothofagus obliqua forest in south-central Chile. Forest Ecology and Management, 2006, vol. 231, no. 1/3, p. 38-46.

SANCHEZ, F.; HONRUBIA, M. and TORRES, P. Effects of $\mathrm{pH}$, water stress and temperatura on in vitro culture of ectomycorrhizal fungi from mediterranean forest. Cryptogamie Mycologie, 2001, vol. 22, no. 4, p. 243-258.

SHI, L.; GUTTENBERGER, M.; KOTTKE, I. and HAMPP, R. The effect of drought on mycorrhizas of beech (Fagus sylvatica L.): changes in community structure, and the content of carbohydrates and nitrogen storage bodies of the fungi. Mycorrhiza, 2002, vol. 12, no. 6, p. 303-311.

SINGER, Rolf. The Agaricales in modern taxonomy. Koenigstein Federal Republic of Germany; Koelz Scientific books 1986. 981 p. ISBN 978-3768201438.

TABATABAI, M. Soil enzymes. In: BIGHAM, J.M. and MICKELSON, S.H. eds. Methods of soil analysis. Wisconsi, USA. Soil Science Society of America, Inc. 1994. Part 2, p 775-833.

TIBBETT, M.; SANDERS, F. and CAIMEY, J. The effect of temperature and inorganic phosphorus supply on growth acid phosphatise production in artic and temperate strains of ectomycorrhizal Hebeloma spp., in axenic culture. Mycological Research, 1998, vol. 102, no. 2, p. 129-135.

TIBBETT, M.; SANDERS, F.; CAIRNEY, J. and LEAKE, J. Temperature regulation of extracellular proteases in ectomycorrhizal fungi (Hebeloma spp.) grown in axenic culture. Mycological Research, 1999, vol. 103, no. 6, p. 707-714.

VALENZUELA, E.; MORENO, G.; GARNICA, S.; GODOY, R. and RAMÍREZ, C. Mycosociology in native forests of Nothofagus of the X Region of Chile, diversity and ecological role. Mycotaxon, 1999, vol. 72, p. 217-226.

VON MERSI, W. and SHINNER, F. Bestimmung der CMCellulase-aktivität. In: SCHINNER, F., ÖHLINGER, R. KANDELER, E. and MARGENSI, R. eds. 
Bodenbiologische Arbeitsmethosem. Springer-Verlag. 1990. p $118-122$.

WRIGHT, D.; READ, D. and SCHOLES, D. Mycorrhizal sink strength influences whole plant carbon balance of Trifolium repens L. Plant Cell and Environment, 1998, vol. 21, p. 881-891.

YAMANAKA, T. The effect of $\mathrm{pH}$ on growth of saprotrophic and ectomycorrhizal ammonia fungi in vitro. Mycologia, 2003, vol. 95, no. 4, p. 584-589. 